Radosław Petrus*

ORCID: 0000-0003-2921-4830

Uniwersytet Wrocławski

https://doi.org/10.19195/1733-5779.30.7

\title{
Koncepcje podstaw skargi kasacyjnej w prawie o postępowaniu przed sądami administracyjnymi
}

\author{
JEL Classification: K, K2, K23
}

Slowa kluczowe: podstawy skargi kasacyjnej, skarga kasacyjna, podstawy kasacyjne

Keywords: grounds for cassation appeal, cassation appeal, cassation grounds

Abstrakt: Artykuł odnosi się do pojęcia i istoty podstaw skargi kasacyjnej w postępowaniu sądowoadministracyjnym. Ich rozumienie i zakres budziły rozbieżności zarówno w doktrynie, jak w orzecznictwie oraz były przedmiotem wielu sporów. Opracowanie opisuje relację skargi kasacyjnej w postępowaniu sądowoadministracyjnym do skargi kasacyjnej z postępowania cywilnego. Artykuł ukazuje ewolucję poglądów orzecznictwa i doktryny w zakresie rozumienia podstaw kasacyjnych. Przybliża też kwestię możliwości zaskarżania skargą kasacyjną innych niż literalnie wskazanych w ustawie naruszeń prawa. Co więcej, prezentuje uzyskane dzięki zabiegom interpretacyjnym takie rozumienie podstaw skargi kasacyjnej, które zapewnia skarżącym skuteczną ochronę prawną.

\section{Concepts of the grounds for cassation appeal in the law on proceedings before administrative courts}

\begin{abstract}
The article refers to the concept and essence of the grounds for cassation appeal in administrative court proceedings. Their understanding and scope has caused discrepancies in both the doctrine and the jurisprudence and has been the subject of many disputes. The study also describes the relation between a cassation appeal in administrative court proceedings and a cassation appeal in civil proceedings. The article shows the evolution of opinions of jurisprudence and doctrine in the understanding of cassation bases. It also brings up the issue of the possibility of appealing in cassation proceedings against infringements of law other than those literally indicated in the act. Moreover, it presents an understanding of the grounds of the cassation appeal obtained by means of the interpretative measures, which provides the plaintiffs with effective legal protection.
\end{abstract}

* Opiekun naukowy (Scientific Tutor) — prof. dr hab. Barbara Adamiak 


\section{Wstęp}

Uregulowanie w rozdziale I działu IV ustawy z dnia 30 sierpnia 2002 roku Prawo o postępowaniu przed sądami administracyjnymi ${ }^{1}$ skargi kasacyjnej wdrożyło do postępowania sądowoadministracyjnego przewidziany w przepisach art. 78 i art. 176 ust. 1 Konstytucji Rzeczypospolitej Polskiej ${ }^{2}$ dwuinstancyjny model postępowania sądowego ${ }^{3}$. Skarga kasacyjna stanowi bowiem środek odwoławczy, przysługujący od orzeczenia wydanego przez wojewódzki sąd administracyjny. W ten sposób można zaskarżyć merytoryczne orzeczenie sądu pierwszej instancji kończące postępowanie w sprawie sądowoadministracyjnej ${ }^{4}$. Istotę skargi kasacyjnej jako środka odwoławczego opisuje sam ustawodawca, wskazując w uzasadnieniu do projektu p.p.s.a., że „Prawo do wniesienia kasacji dotyczy wszystkich sytuacji, gdy sąd w sprawie orzeka co do meritum w zakresie swojej właściwości. W ten sposób zagwarantowana zostanie przewidziana w Konstytucji dwuinstancyjność sądowej kontroli działalności administracji publicznej"5.

Należy jednak pamiętać, że skarga kasacyjna jako środek odwoławczy cechuje się wysokim formalizmem. Jednym z jego przejawów jest konieczność oparcia skargi kasacyjnej na enumeratywnie określonych podstawach zaskarżenia. Zgodnie z przepisem art. $176 \S 1$ pkt 2 p.p.s.a. jednym z wymogów formalnych skargi kasacyjnej jest przytoczenie podstaw kasacyjnych i ich uzasadnienie. Jak natomiast wskazuje przepis art. $183 \S 1$ p.p.s.a., Naczelny Sąd Administracyjny rozpoznaje sprawę w granicach skargi kasacyjnej. Zgodnie z orzecznictwem NSA „Związanie granicami skargi kasacyjnej dotyczy związania przytoczonymi podstawami kasacyjnymi, rozumianymi jako wskazanie przepisów prawa, które — zdaniem wnoszącego skargę kasacyjną — zostały naruszone przez sąd pierwszej instancji" ${ }^{\prime}$. W doktrynie podnosi się, że ograniczenie skutecznego wniesienia skargi kasacyjnej do taksatywnie wyliczonych wad orzeczenia czyni ją środkiem odwoławczym o charakterze niepełnym ${ }^{7}$. Godzi się zatem uznać, że sposób sformułowania zarzutów skargi kasacyjnej decyduje o jej dopuszczalności oraz wyznacza zakres kontroli instancyjnej dokonywanej przez Naczelny Sąd Administracyjny. Jednocześnie, jak zaznaczono, zarzuty do orzeczenia wojewódzkiego

1 Dz.U. z 2018 r. poz. 1302 z późn. zm.

2 Dz.U. z 1997 r. Nr 78, poz. 483 z późn. zm.

3 M. Niezgódka-Medek, [w:] Prawo o postępowaniu przed sądami administracyjnymi. Komentarz, red. B. Dauter, A. Kabat, M. Niezgódka-Medek, Warszawa 2016, s. 740-741; J. Drachal, A. Wiktorowska, R. Stankiewicz, [w:] Prawo o postępowaniu przed sadami administracyjnymi. Komentarz, red. R. Hauser, M. Wierzbowski, Warszawa 2017, s. 687.

${ }^{4}$ H. Knysiak-Sudyka, Skarga i skarga kasacyjna w postepowaniu sadowoadministracyjnym, Warszawa 2016, s. 165-166.

${ }^{5}$ http://orka.sejm.gov.pl/Druki4ka.nsf/(\$vAllByUnid)/F1991C948C3387B5C1256AF1006055 84/\$file/19-uzasadnienie.pdf (dostęp: 1.10.2019), s. 9.

6 Wyrok NSA z dnia 27 lutego 2019 roku, II OSK 910/17, LEX nr 2639398.

${ }^{7}$ H. Knysiak-Sudyka, op. cit., s. 208. 
sądu administracyjnego oprzeć można jedynie na enumeratywnie wyliczonych w przepisie art. 174 p.p.s.a. podstawach kasacyjnych, który to katalog nie zawiera jednak wszystkich znanych doktrynie i orzecznictwu form naruszeń prawa. Jak wskazuje zaś w swoim orzecznictwie ETPCz, środek odwoławczy musi być skuteczny zarówno w praktyce, jak i prawie, w tym sensie, że daje możliwość naprawienia zakwestionowanego stanu rzeczy ${ }^{8}$.

Stąd też rodzi się następujące pytanie: czy wobec taksatywnego określenia podstaw jej wniesienia skarga kasacyjna w postępowaniu sądowoadministracyjnym zapewnia skarżącemu skuteczną ochronę prawną, także w wypadkach, które nie zostały wprost określone w przepisie art. 174 p.p.s.a.?

Celem niniejszego opracowania jest przeanalizowanie każdej z określonych w przepisie art. 174 p.p.s.a. podstaw kasacyjnych oraz próba udzielenia odpowiedzi na zadane pytanie. W niniejszej pracy postaram się ponadto wykazać, że dzięki zabiegom interpretacyjnym podjętym przede wszystkim przez orzecznictwo NSA, jak również przez naukę prawa, obecna redakcja podstaw skargi kasacyjnej zapewnia skarżącemu skuteczną ochronę prawną.

\section{Pojęcie podstaw skargi kasacyjnej}

Próbując zdefiniować pojęcie podstaw skargi kasacyjnej (podstaw kasacyjnych, podstaw zaskarżenia), należy najpierw określić znaczenie terminu ,podstawa”. Zgodnie ze słownikowym pojęciem ,,podstawa” oznacza „rzecz, na której coś stoi, opiera się” oraz określana jest jako, ,zasada, podwalina czegoś”9. Już sama przedstawiona ogólna i pozbawiona treści prawnych definicja wskazuje na zasadnicze znaczenie podstaw skargi kasacyjnej w jej konstrukcji.

Podejmując próbę zdefiniowania tych pojęć, należy również pamiętać o relacji skargi kasacyjnej w postępowaniu sądowoadministracyjnym do kasacji ure-

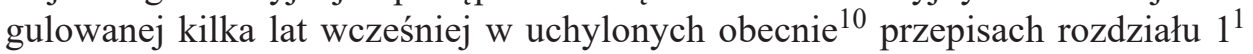
działu V tytułu VI księgi pierwszej części pierwszej ustawy z dnia 17 listopada 1964 roku Kodeks postępowania cywilnego ${ }^{11}$. Jak bowiem wskazano w uzasadnieniu do

${ }^{8}$ Wyrok ETPC z z dnia 10 kwietnia 2008 roku, nr skargi 21071/05, LEX nr 370471.

${ }^{9}$ https://sjp.pwn.pl/sjp/podstawa;2502784.html (dostęp: 1.10.2019).

10 Rozdział $1^{1}$ działu V tytułu VI księgi pierwszej części pierwszej k.p.c. został uchwalony ustawą z dnia 1 marca 1996 roku o zmianie Kodeksu postępowania cywilnego, rozporządzeń Prezydenta Rzeczypospolitej — Prawo upadłościowe i Prawo o postępowaniu układowym, Kodeksu postępowania administracyjnego, ustawy o kosztach sądowych w sprawach cywilnych oraz niektórych innych ustaw (Dz.U. z 1996 r. Nr 43, poz. 189), a następnie został uchylony w drodze ustawy z dnia 22 grudnia 2004 roku o zmianie ustawy Kodeks postępowania cywilnego oraz ustawy Prawo o ustroju sądów powszechnych (Dz.U. z 2005 r. Nr 13, poz. 98). Obecnie skarga kasacyjna jest uregulowana przepisach działu Va, tytułu VI, księgi pierwszej, części pierwszej k.p.c.

11 Dz.U. z 2019 r. poz. 1460 z poźn. zm. 
projektu p.p.s.a. „Podstawy kasacji są zbliżone do podstaw kasacji w postępowaniu cywilnym, z odrębnościami, które proponuje się przewidzieć w ustawie"12.

Analizując poglądy doktryny postępowania cywilnego oraz orzecznictwo sądów powszechnych, podstawy kasacyjne należałoby rozumieć jako przyczyny, na których można oprzeć zaskarżenie orzeczenia ${ }^{13}$ oraz jako konkretne przepisy prawa, które zostały wskazane w skardze kasacyjnej z jednoczesnym stwierdzeniem, że wydanie wyroku nastąpiło z ich obrazą ${ }^{14}$. J.P. Tarno rozumie ,,podstawy kasacji” jako „przyczyny, na podstawie których można zaskarżyć orzeczenie sądu administracyjnego pierwszej instancji”"15.

Przedstawione definicje cechują się dużym stopniem ogólności lub eksponują techniczne kwestie związane z wymogami formalnymi skargi kasacyjnej. Elementem łączącym te definicje jest fakt, że ujmują one pojęcie podstaw kasacyjnych od strony skarżącego konkretne orzeczenie. Eksponują one bowiem subiektywne twierdzenia skarżącego o wystąpieniu w danym orzeczeniu wad i błędów, które uzasadniają konieczność uchylenia lub zmiany zaskarżonego orzeczenia.

Z kolei W. Piątek definiuje podstawy skargi kasacyjnej jako „określone ustawowo uchybienia, które mogą być przedmiotem formułowania zarzutów przez skarżącego pod adresem wyroku WSA, prowadzących do uchylenia albo zmiany zaskarżonego wyroku""16. Wydaje się jednak, że ten pogląd nie uwzględnia, że, co oczywiste, samo twierdzenie skarżącego o wystąpieniu w danym orzeczeniu WSA uchybień wskazanych w przepisie art. 174 p.p.s.a. nie zawsze będzie podzielone przez rozpoznający skargę kasacyjną Naczelny Sąd Administracyjny, a zatem twierdzenie o wystąpieniu danych uchybień nie zawsze będzie prowadzić do uchylenia lub zmiany zaskarżonego wyroku. Odnosząc się do powyższego, nie sposób pominąć również treści przepisu art. $183 \S 1$ p.p.s.a., zgodnie z którym Naczelny Sąd Administracyjny rozpoznaje sprawę w granicach skargi kasacyjnej, bierze jednak z urzędu pod rozwagę nieważność postępowania. W tym zakresie należy podzielić pogląd G. Rząsy, który stoi na stanowisku, że ,definicji podstaw skargi kasacyjnej w p.p.s.a. nie można ograniczać do wskazanych w art. 174 uchybień (naruszeń prawa), które skarżący może wytknąć (powołać) w tym środku

12 http://orka.sejm.gov.pl/Druki4ka.nsf/(\$vAllByUnid)/F1991C948C3387B5C1256AF1006055 84/\$file/19-uzasadnienie.pdf (dostęp: 1.10.2019), s. 9.

13 T. Ereciński, [w:] Kodeks postępowania cywilnego. Komentarz, t. 3. Postępowanie rozpoznawcze, red. T. Ereciński, Warszawa 2016, s. 219.

14 Wyrok SN z dnia 10 listopada 2010 roku, I UK 135/10, LEX nr 707407; wyrok SN z dnia 24 marca 2011 roku, I UK 317/10, LEX nr 1130858.

15 J.P. Tarno, Prawo o postępowaniu przed sądami administracyjnymi. Komentarz, Warszawa 2012, s. 445.

16 W. Piątek, Podstawy skargi kasacyjnej w postępowaniu sądowoadministracyjnym, Warszawa 2011, s. 45-46. 
zaskarżenia"17. Należy również pamiętać o treści przepisu art. 184 p.p.s.a., zgodnie z którym Naczelny Sąd Administracyjny oddala skargę kasacyjną, nawet jeżeli zaskarżone orzeczenie mimo błędnego uzasadnienia odpowiada prawu. Godzi się zatem uznać, że nawet mimo podzielenia przez Naczelny Sąd Administracyjny twierdzeń skarżącego o wystąpieniu w danym orzeczeniu ustawowo określonych uchybień, zaskarżone orzeczenie nie zawsze zostanie uchylone lub zmienione. G. Rząsa, po dokonaniu analizy ukształtowanych w piśmiennictwie poglądów, jako podstawy skargi kasacyjnej w postępowaniu sądowoadministracyjnym rozumie przyczyny (okoliczności), których zaistnienie może doprowadzić do uchylenia zaskarżonego w drodze skargi kasacyjnej orzeczenia wojewódzkiego sądu administracyjnego ${ }^{18}$.

Cechą charakterystyczną przedstawionych definicji jest, że ujmują one pojęcie podstaw skargi kasacyjnej z punktu widzenia sądu odwoławczego. Opisane definicje utożsamiają bowiem podstawy skargi kasacyjnej z przyczynami, których wystąpienie powinno skutkować wyeliminowaniem zaskarżonego orzeczenia z obrotu.

Po analizie rzeczonych definicji, w moim przekonaniu, pod pojęciem podstaw skargi kasacyjnej należy rozumieć ustawowo i enumeratywnie określone rodzaje naruszeń, na podstawie których skarżący może oprzeć skargę kasacyjną wobec orzeczenia wojewódzkiego sądu administracyjnego, co z kolei, w razie uwzględnienia zarzutów skarżącego przez Naczelny Sąd Administracyjny, może skutkować uchyleniem lub zmianą zaskarżonego orzeczenia. Ta definicja jest próbą pogodzenia pojęcia podstaw skargi kasacyjnej z perspektywy zarówno sądu odwoławczego, jak i podmiotu skarżącego. Stara się ona również uwzględnić okoliczności wskazane w przepisie art. 184 p.p.s.a. Co więcej, zaproponowana definicja zawierająca określenie ,ustawowo i enumeratywnie określone rodzaje naruszeń" nie stoi w sprzeczności z zaprezentowanymi w dalszej części opracowania rozważaniami co do dopuszczalności formułowania na przykład zarzutu naruszenia prawa ustrojowego. Takiego rodzaju zarzut będzie w konkretnym wypadku czyniony poprzez wskazanie jednej z obecnie istniejących podstaw, o czym szerzej w dalszej części opracowania.

Przechodząc zaś do podstaw skargi kasacyjnej w p.p.s.a., należy wskazać, że zgodnie z przepisem art. 174 p.p.s.a. skargę kasacyjną można oprzeć na następujących podstawach: 1. naruszenie prawa materialnego przez błędną jego wykładnię lub niewłaściwe zastosowanie; 2. naruszenie przepisów postępowania, jeżeli uchybienie to mogło mieć istotny wpływ na wynik sprawy.

17 G. Rząsa, Podstawy skargi kasacyjnej w postępowaniu sądowoadministracyjnym, „Państwo i Prawo" 2008, nr 8, s. 57-58.

18 Ibidem, s. 56-58. 


\section{Naruszenie prawa materialnego}

Pierwsza podstawa skargi kasacyjnej obejmuje dwupostaciowo wyrażone naruszenie prawa materialnego: błędna wykładnia lub niewłaściwe zastosowanie. Aby przejść do charakterystyki tych podstaw, konieczne jest wyjaśnienie pojęcia prawa materialnego.

J. Jagielski, po dokonaniu kompleksowej analizy doktryny prawa administracyjnego, rozumie prawo administracyjne materialne jako

zespół norm prawa administracyjnego, wiążących bezwzględnie, obligatoryjnych, zawartych w źródłach prawa powszechnie obowiązującego, adresowanych do jednostek (osób i innych podmiotów niepodporządkowanych organizacyjnie administracji publicznej), których treścią jest wyznaczenie sytuacji prawnej adresatów poprzez określenie ich praw i powinności oraz warunków i przesłanek ich zaistnienia, i które to normy oddziaływać mogą w swych treściach bezpośrednio (wprost, $\mathrm{z}$ mocy ustawy) bądź poprzez ich konkretyzację w procesie stosowania prawa, tj. w drodze stosownych działań (przede wszystkim wydawanie aktów administracyjnych, ale także i podejmowanie czynności materialnotechnicznych) upoważnionych podmiotów administrujących; w tym drugim przypadku treść norm prawnomaterialnych obejmuje również określenie właściwego podmiotu administrującego ${ }^{19}$.

Na marginesie należy zaznaczyć, że do określenia, czy dana norma prawna zalicza się do prawa materialnego, nie ma znaczenia, w jakim akcie prawnym się ona znajduje. Tytułem przykładu można wskazać przepis art. 28 k.p.a., który pomimo faktu umieszczenia go w ustawie regulującej postępowanie administracyjne zawiera normy prawa materialnego regulujące kwestię strony postępowania administracyjnego ${ }^{20}$. Strona postępowania administracyjnego jest wprawdzie instytucją procesową, jednak statuujące ją pojęcie interesu prawnego wynika z konkretnej $i$ zindywidualizowanej normy prawa materialnego ${ }^{21}$. Należy zatem dojść do przekonania, że do ustalenia, czy określoną normę prawną można uznać za normę prawa materialnego, kluczowe znaczenie będzie miała odpowiedź na pytanie, czy ta norma zawiera opisane wcześniej elementy charakterystyczne dla administracyjnego prawa materialnego. W razie pozytywnej odpowiedzi na wskazane pytanie określoną normę prawną należy uznawać za normę prawa administracyjnego, niezależnie od aktu prawnego, w jakim się ona znajduje.

Naruszenie prawa materialnego poprzez błędną wykładnię rozumiane jest jako nieprawidłowe w odniesieniu do przyjętych reguł wykładni rozumienie treści obowiązującego przepisu ${ }^{22}$ lub też jako nieprawidłowe odczytanie normy prawnej

19 J. Jagielski, [w:] System Prawa Administracyjnego, t. 7. Prawo administracyjne materialne, red. R. Hauser, Z. Niewiadomski, A. Wróbel, Warszawa 2012, s. 33-34.

20 Wyrok NSA z dnia 27 czerwca 2006 roku, I OSK 641/05, LEX nr 266347.

21 Wyrok NSA z dnia 6 czerwca 2017 roku, I OSK 2354/15, LEX nr 2468901.

${ }^{22}$ H. Knysiak-Sudyka, op. cit., s. 211. 
wyrażonej w przepisie ${ }^{23}$, mylne zrozumienie jego treści ${ }^{24}$ lub znaczenia prawnego bądź też jako niezrozumienie intencji ustawodawcy ${ }^{25}$. B. Adamiak, odwołując się do dyrektyw interpretacji pierwszego stopnia, wskazuje, że „Błędna wykładnia wojewódzkiego sądu administracyjnego polega na nieuwzględnieniu reguł interpretacji przepisów prawa administracyjnego nakazujących stosowanie wykładni: językowej, systemowej i funkcjonalnej" 26 .

Drugą wymienioną w przepisie art. 174 pkt 1 p.p.s.a. formą naruszenia prawa materialnego jest jego niewłaściwe zastosowanie.

Kluczowe dla prawidłowej charakterystyki powyższego zagadnienia wydaje się wyjaśnienie pojęcia stosowania prawa przez sąd administracyjny. Zgodne z koncepcją J. Wróblewskiego stosowanie prawa obejmuje cztery etapy:

1. ustalenie, jaka norma obowiązuje w znaczeniu dostatecznie określonym na potrzeby rozstrzygnięcia;

2. uznanie za udowodniony faktu na podstawie określonych materiałów i na podstawie przyjętej teorii dowodów oraz ujęcie tego faktu w języku stosowanej normy;

3. subsumpcja faktu uznanego za udowodniony pod stosowaną normę prawną;

4. wiążące ustalenie konsekwencji prawnych faktu uznanego za udowodniony na podstawie stosowanej normy prawnej ${ }^{27}$.

Jak słusznie wskazuje Z. Kmieciak, sąd administracyjny w odróżnieniu od organu administracji publicznej nie ustala w sposób wiążący konsekwencji prawnych faktów uznanych uprzednio za udowodnione. Ujmując tę kwestię w jeszcze bardziej dosadny sposób, H. Knysiak-Sudyka podkreśla, że stosowanie prawa materialnego odbywa się przed organem administracji publicznej na etapie prowadzonego postępowania administracyjnego, sąd administracyjny zaś ocenia prawidłowość opisanego procesu ${ }^{28}$. Wątpliwości w zakresie rozumienia pojęcia stosowania prawa przez sądy administracyjne wynikają z faktu, że, jak już kilkakrotnie zaznaczano, regulacja skargi kasacyjnej w p.p.s.a. została zaprojektowana na podstawie regulacji kasacji (a obecnie skargi kasacyjnej) z postępowania cywilnego. Sądy administracyjne, co wiąże się z realizowaniem przez nie funkcji kontrolnej wobec organów administracji publicznej, weryfikują zgodność z pra-

23 S. Babiarz, K. Aromiński, [w:] Postępowanie sądowoadministracyjne w praktyce, red. S. Babiarz, Warszawa 2015, s. 198; W. Piątek, op. cit., s. 221.

24 B. Dauter, Metodyka pracy sędziego sądu administracyjnego, Warszawa 2012, s. 533; J.P. Tarno, op. cit., s. 446.

25 Wyrok NSA z dnia 5 czerwca 2014 roku, I OSK 294/14, LEX nr 1518050; wyrok NSA z dnia 11 czerwca 2014 roku, I OSK 575/14, LEX nr 1484868.

26 B. Adamiak, Skarga i skarga kasacyjna w postępowaniu sadowoadministracyjnym. Komentarz, Warszawa 2017, s. 800.

27 J. Wróblewski, Sądowe stosowanie prawa, Warszawa 1972, s. 52.

28 H. Knysiak-Sudyka, op. cit., s. 212. 
wem ustaleń poczynionych przez te organy ${ }^{29}$. W ramach tej kontroli sądy administracyjne uprawnione są do formułowania tak zwanych zwrotów stosunkowych, kwalifikujących zaskarżone zachowania organów administracji publicznej jako zgodnych albo niezgodnych z prawem, na podstawie porównania tychże zachowań z normami odniesienia (będącymi podstawą działania sądu jako organu kontroli) i norm dopełnienia (dotyczących poddanych kontroli sądowej zachowań organów administracji publicznej) ${ }^{30}$.

Na podstawie wykładni funkcjonalnej należałoby zatem uznać, że wojewódzki sąd administracyjny $\mathrm{w}$ istocie stosuje prawo, czyniąc z przepisów prawa materialnego wzorzec kontroli legalności zaskarżonych działań organów administracji publicznej ${ }^{31}$. Takie rozumienie treści przepisu art. 174 pkt 1 p.p.s.a. pozwala uniknąć skądinąd absurdalnego wniosku, że projektując p.p.s.a., ustawodawca bezwiednie dokonał kalki z postępowania cywilnego, jakkolwiek nie uwzględniając istotnych różnic między tymi dwoma postępowaniami. Jak słusznie zauważa Z. Kmieciak, „Nie do zaakceptowania byłby bowiem pogląd, że ustawodawca określił podstawę kasacyjną, która w ogóle nie mogłaby znaleźć zastosowania"32.

Przechodząc do sedna, niewłaściwe zastosowanie prawa materialnego w rozumieniu przepisu art. 174 pkt 1 p.p.s.a. zachodzi, gdy sąd administracyjny wadliwie ocenia dokonaną subsumpcję faktu uznanego za udowodniony pod stosowaną normę prawną ${ }^{33}$ lub gdy stan faktyczny ustalony w sprawie błędnie uznano za odpowiadający stanowi hipotetycznemu przewidzianemu w normie prawnej albo gdy ustalonego stanu faktycznego błędnie nie ,podciągnięto” pod hipotezę określonej normy prawnej ${ }^{34}$. Uznaje się również, że to naruszenie polega na niezasadnym przyjęciu bądź zaprzeczeniu przez sąd związku, jaki zachodzi między stanem faktycznym ustalonym w postępowaniu a abstrakcyjnym stanem faktycznym normy prawnej $^{35}$. W orzecznictwie natomiast podnosi się, że niewłaściwe zastosowanie przepisu, czyli błąd w subsumpcji, oznacza wadliwe uznanie, że ustalony w sprawie konkretny stan faktyczny odpowiada abstrakcyjnemu stanowi faktycznemu określonemu w hipotezie normy prawnej ${ }^{36}$ albo błędne niepodciągnięcie pod hi-

${ }^{29}$ Z. Kmieciak, Czy sady administracyjne stosuje przepisy prawa materialnego?, „Zeszyty Naukowe Sądownictwa Administracyjnego" 2011, nr 2, s. 12.

30 J. Borkowski, [w:] B. Adamiak, J. Borkowski, Metodyka pracy sędziego w sprawach administracyjnych, Warszawa 2015, s. 65-66.

31 S. Babiarz, K. Aromiński, op. cit., s. 198-199.

32 Z. Kmieciak, Podstawy skargi kasacyjnej do Naczelnego Sąu Administracyjnego, „Państwo i Prawo" 2005, nr 1, s. 21.

33 B. Adamiak, J. Borkowski, [w:] Metodyka pracy sędziego w..., s. 329.

34 J.P. Tarno, op. cit., s. 446 i przywołane tam orzecznictwo.

35 R. Hauser, W. Piątek, A. Skoczylas, [w:] System Prawa Administracyjnego, t. 10. Sądowa kontrola administracji publicznej, red. R. Hauser, Z. Niewiadomski, A. Wróbel, Warszawa 2016, s. 447.

36 Wyrok NSA z dnia 18 maja 2011 roku, I OSK 114/11, LEX nr 990149. 
potezę określonej normy prawnej ustalonego stanu faktycznego ${ }^{37}$. Istotą tej formy naruszenia, zwłaszcza w kontekście wcześniejszych rozważań na temat stosowania przez sądy administracyjne prawa materialnego, jest dokonanie przez wojewódzki sąd administracyjny nieprawidłowej oceny zastosowania prawa materialnego przez organ administracji publicznej ${ }^{38}$.

W doktrynie i judykaturze nie ma zgodności stanowisk co do dopuszczalności równoczesnego zarzucenia w skardze kasacyjnej naruszenia prawa materialnego przez jego błędną wykładnię i niewłaściwe zastosowanie. Początkowo podnoszono, że takie sformułowanie zarzutów jest błędne ${ }^{39}$ i niedopuszczalne ${ }^{40}$, albowiem błędna wykładnia i niewłaściwe zastosowanie to dwie odrębne postacie naruszenia prawa materialnego ${ }^{41}$, które nie mogą zachodzić jednocześnie ${ }^{42}$. Obecnie zdaje się jednak przeważać pogląd dopuszczający taki sposób sformułowania zarzutów, gdy niewłaściwe zastosowanie przepisu prawa materialnego jest konsekwencją jego błędnej wykładni ${ }^{43}$. Oprócz tego wariantu naruszeń może zaistnieć również błąd podwójny niezależny, polegający na tym, że dokonujący wykładni nie tylko wadliwie przyjął, że ustalony stan faktyczny odpowiada hipotezie określonej normy prawnej, lecz także, stosując ją, błędnie odczytał dyspozycję lub sankcję, czym dokonał błędu w subsumpcji ${ }^{44}$. Co więcej, jak słusznie zauważa G. Rząsa, w wypadku posługiwania się przez ustawodawcę ogólnymi pojęciami prawnymi (na przykład pojęciem interesu publicznego) wykładnia i subsumpcja ściśle się z sobą wiążą, w związku z czym wytyczenie granicy między nimi może napotykać poważne trudności ${ }^{45}$.

Opisując możliwe formy naruszenia prawa materialnego, należy zaznaczyć, że część doktryny uznaje, iż istnieje również trzecia forma jego naruszenia, która polega na zastosowaniu przepisu nieobowiązującego lub pominięciu przepisu

37 Wyrok NSA z dnia 9 grudnia 2011 roku, II FSK 1142/10; LEX 1112709; wyrok NSA z dnia 3 kwietnia 2014 roku, II OSK 2664/12; LEX nr 1575562.

38 Z. Kmieciak, Podstawy skargi kasacyjnej..., s. 19; H. Knysiak-Sudyka, op. cit., s. 212; wyrok NSA z dnia 23 lutego 2011 roku, II GSK 277/10, LEX nr 1071124.

39 G. Borkowski, Skarga kasacyjna - po roku obowiazywania ustawy, „Monitor Podatkowy” 2005, nr 3, s. 18.

40 Wyrok NSA z dnia 16 grudnia 2005 roku, I FSK 423/05, LEX nr 187703.

41 Wyrok NSA z dnia 7 października 2004 roku, FSK 558/04, LEX nr 251771.

42 Wyrok NSA z dnia 8 września 2005 roku, OSK 1950/04, LEX nr 194728; wyrok NSA z dnia 24 maja 2004 roku, FSK 78/04, LEX nr 707780; wyrok NSA z dnia 24 maja 2004 roku, FSK 79/04, LEX nr 109935.

${ }^{43}$ B. Dauter, B. Gruszczyński, [w:] Prawo o postępowaniu przed sądami administracyjnymi. Komentarz, red. B. Dauter et al., Warszawa 2011, s. 538; H. Knysiak-Sudyka, op. cit., s. 213; J.P. Tarno, op. cit., s. 461; J. Drachal, A. Wiktorowska, R. Stankiewicz, op. cit., s. 694.

44 B. Dauter, B. Gruszczyński, op. cit., s. 538.

45 G. Rząsa, op. cit., s. 64. 
obowiązującego ${ }^{46}$. To naruszenie nazywane jest „naruszeniem prawa w ścisłym tego słowa znaczeniu” 47 lub jeszcze bardziej dosadnie — ,pogwałceniem prawa w ścisłym tego słowa znaczeniu" 48 .

Mając na uwadze rzeczone całkowicie zasadnie rodzi się następujące pytanie: skoro „naruszenie (pogwałcenie) prawa w ścisłym tego słowa znaczeniu” jest jedną $\mathrm{z}$ form naruszeń przepisów prawa materialnego, to na podstawie której z form naruszeń wymienionych w przepisie art. 174 pkt 1 p.p.s.a. należy podnosić tego rodzaju zarzut? Inaczej: czy to naruszenie stanowi błędną wykładnię, czy niewłaściwe zastosowanie prawa materialnego?

Zgodnie $\mathrm{z}$ jednym istniejącym $\mathrm{w}$ doktrynie $\mathrm{i}$ orzecznictwie nurtem naruszenie prawa $\mathrm{w}$ ścisłym znaczeniu utożsamia się z błędną wykładnią prawa materialnego. Podejmując próbę określenia, czym jest błąd wykładni, W. Piątek wskazuje, że polega on między innymi na zastosowaniu normy prawnej nieistniejącej albo pominięciu w procesie wykładni normy prawnej istniejącej ${ }^{49}$. Z kolei B. Adamiak, opisując naruszenie prawa materialnego poprzez błędną wykładnię, podnosi, że ten rodzaj naruszenia „obejmuje błędną wykładnię co do mocy obowiązującej normy prawnej" ${ }^{50}$. H. Knysiak-Sudyka wskazuje z kolei, że błąd wykładni oznacza między innymi zastosowanie przepisu nieobowiązującego ${ }^{51}$. W orzecznictwie natomiast uznaje się, że błędna wykładnia prawa materialnego może się przejawiać między innymi zastosowaniem nieobowiązującego (uchylonego) ${ }^{52}$.

Zgodnie z odmiennym poglądem naruszenie prawa sensu stricto należy utożsamiać z naruszeniem prawa materialnego poprzez niewłaściwe zastosowanie. Uznaje się bowiem, że niewłaściwe zastosowanie prawa może polegać na pominięciu obowiązującego przepisu, który powinien zostać zastosowany w konkretnej sprawie, ewentualnie na zastosowaniu przepisu, który nie powinien mieć w danej sprawie zastosowania $^{53}$. G. Rząsa, uznając, że taka interpretacja znajduje oparcie w wykładni językowej przepisu art. 174 pkt 1 p.p.s.a., a ponadto odpowiada ona logicznej sekwencji budowania orzeczenia sądowego, twierdzi, że zarzut naruszenia prawa sensu stricto powinien przybrać formę zarzutu naruszenia prawa materialne-

46 Ibidem, s. 62-63; J. Lapierre, [w:] J. Jodłowski et al., Postępowanie cywilne, Warszawa 2016, s. 558; B. Dauter, B. Gruszczyński, op. cit., s. 538-539; A. Zieliński, [w:] Kodeks postępowania cywilnego. Komentarz, red. A. Zieliński, Warszawa 2017, s. 741; wyrok NSA z dnia 13 grudnia 2007 roku, II OSK 1707/06, LEX nr 428117.

47 G. Rząsa, op. cit., s. 62-63; J. Lapierre, op. cit., s. 558.

48 R. Hauser, W. Piątek, A. Skoczylas, op. cit., s. 446-447.

49 W. Piątek, op. cit., s. 310.

50 B. Adamiak, J. Borkowski, [w:] Metodyka pracy sędziego w..., s. 329.

${ }^{51}$ H. Knysiak-Sudyka, op. cit., s. 211.

52 Wyrok NSA z dnia 13 września 2005 roku, II OSK 16/05, LEX nr 192124; wyrok NSA z dnia 18 maja 2011 roku, I OSK 114/11, LEX nr 990149; wyrok NSA z dnia 29 sierpnia 2019 roku, I OSK 2554/18, LEX nr 2725491.

53 S. Babiarz, K. Aromiński, op. cit., s. 203. 
go przez niewłaściwe zastosowanie ${ }^{54}$. Mając na uwadze opisany na początku opracowania fakt, że ustawodawca, projektując skargę kasacyjną w p.p.s.a., oparł się na wcześniej istniejącej regulacji kasacji (obecnie skargi kasacyjnej) w postępowaniu cywilnym, zasadne wydaje się również uwzględnienie poglądów doktryny postępowania cywilnego. Uznaje się bowiem, że niewłaściwe zastosowanie prawa materialnego może przybrać formę naruszenia prawa sensu stricto, a to na skutek zastosowania normy prawnej nieistniejącej, która została uchylona albo jeszcze nie obowiązuje ${ }^{55}$. Z kolei NSA w swoim orzecznictwie uznał, że naruszenie prawa materialnego przez niewłaściwe zastosowanie wyraża się pominięciem obowiązującego przepisu, który powinien być zastosowany w konkretnej sprawie ${ }^{56}$ lub zastosowaniem przepisu niewłaściwego 57 .

Niezależnie od tego, którą z opisanych koncepcji przyjmie się za zasadną, należy zgodzić się z G. Rząsą, który wskazuje, że „Niewymienienie przez ustawodawcę w art. 174 pkt 1 p.p.s.a. tego typu naruszenia prawa [naruszenia prawa sensu stricto - R.P.] nie oznacza, oczywiście, że nie może być ono podstawą skargi kasacyjnej - ustawodawca pominął ten rodzaj uchybień sądu, mając na uwadze zasadę iura novit curia" 58 .

Poczynione rozważania prowadzą do wniosku, że pomimo niewymienienia naruszenia prawa sensu stricto w katalogu zawartym w przepisie art. 174 p.p.s.a. można w skardze kasacyjnej skutecznie podnosić powyższy zarzut na podstawie obecnie funkcjonujących podstaw kasacyjnych.

\section{Naruszenie przepisów postępowania}

Drugą z podstaw skargi kasacyjnej, określoną w przepisie art. 174 pkt 2 p.p.s.a., jest naruszenie przepisów postępowania, jeżeli uchybienie to mogło istotnie wpłynąć na wynik sprawy. Jak wskazuje H. Knysiak-Sudyka, przepisy prawa procesowego stanowią normy instrumentalne, określające drogę i sposób dochodzenia uprawnień wynikających z norm materialnoprawnych, służące realizacji obowiązków i uprawnień określonych normami prawa materialnego ${ }^{59}$. Podobne zapatrywanie wyraża Z. Duniewska, podnosząc, że administracyjne prawo proceduralne to zbiór przepisów regulujących procedury działania organów państwowych i in-

54 G. Rząsa, op. cit., s. 63.

55 A. Piotrowska, [w:] Kodeks postępowania cywilnego, t. 2, red. A. Marciniak, K. Piasecki, Warszawa 2016, s. 122.

56 Wyrok NSA z dnia 27 lipca 2006 roku, I FSK 1130/05, LEX nr 279045; wyrok NSA z dnia 27 lipca 2006 roku, I FSK 643/05, LEX nr 279049; wyrok NSA z dnia 21 września 2006 roku, I FSK 594/05, LEX nr 280933.

57 Wyrok NSA z dnia 6 lipca 2006 roku, I FSK 1122/05, LEX nr 279043.

58 G. Rząsa, op. cit., s. 63 i przywołana tam literatura.

59 H. Knysiak-Sudyka, op. cit., s. 217. 
nych podmiotów publicznych, którym przyznano kompetencje do tworzenia i stosowania prawa ${ }^{60}$.

Odnosząc się do możliwych form naruszeń przepisów postępowania, w doktrynie wskazuje się, że są one tożsame z formami naruszeń prawa materialnego, a zatem powyższe naruszenie może polegać na błędzie wykładni lub na błędzie subsumpcji. Granicą między błędem wykładni a błędem subsumpcji jest zakończenie procesu interpretacji tego prawa - do tego momentu wszelkie błędy powinny być postrzegane jako błędy wykładni ${ }^{61}$.

Czynnikiem decydującym o skuteczności zarzutu opartego na przepisie art. 174 pkt 2 p.p.s.a. jest istnienie związku przyczynowego między uchybieniem procesowym a zaskarżonym orzeczeniem - podniesiony przez skarżącego zarzut naruszenia przepisów postępowania będzie zasadny, tylko gdy wskazywane uchybienie mogło mieć istotny wpływ na wynik sprawy. Opisany związek przyczynowy nie musi być jednak realny ${ }^{62}$, lecz musi być istotny, co z kolei należy wiązać z hipotetycznymi następstwami uchybień przepisom postępowania. Oznacza to, że następstwa stwierdzonych uchybień były tak istotne, iż kształtowały lub współkształtowały treść kwestionowanego orzeczenia ${ }^{63}$.

Zarówno w doktrynie, jak i orzecznictwie szerokie wątpliwości interpretacyjne budzi kwestia zakresu pojęcia „przepisy postępowania” użytego przez ustawodawcę w przepisie art. 174 pkt 2 p.p.s.a. Zastanawiano się, czy to pojęcie swym zakresem obejmuje tylko przepisy postępowania sądowoadministracyjnego, czy również przepisy postępowania administracyjnego.

$Z$ jednej strony podnosi się, że

podstawą skargi kasacyjnej [wskazaną w przepisie art. 174 pkt 2 p.p.s.a. - R.P.] jest naruszenie przez wojewódzki sąd administracyjny przepisów postępowania sądowoadministracyjnego. Natomiast ciężkie kwalifikowane naruszenie przepisów postępowania administracyjnego przez organ wykonujący administrację publiczną będące podstawą wznowienia postępowania [...] lub naruszenie innych przepisów postępowania, które mogło mieć istotny wpływ na wynik sprawy, a nie zostało dostrzeżone przez wojewódzki sąd administracyjny, ulega sanacji i nie może być podstawą skargi kasacyjnej ${ }^{64}$.

Podobne stanowisko wyraża Z. Kmieciak, który wskazuje ponadto, że sądy administracyjne co do zasady rozpoznają sprawy na podstawie akt sprawy, a za-

60 Z. Duniewska, [w:] System prawa administracyjnego, t. 1. Instytucje Prawa Administracyjnego, red. R. Hauser, Z. Niewiadomski, A. Wróbel, Warszawa 2015, s. 141.

61 Szerzej W. Piątek, op. cit., s. 311.

62 H. Knysiak-Sudyka, op. cit., s. 217; wyrok NSA z dnia 15 lutego 2017 roku, II FSK 2986/16, LEX nr 2270044.

63 Wyrok NSA z dnia 20 marca 2012 roku, II FSK 1760/10, LEX nr 1295991; wyrok NSA z dnia 20 lutego 2014 roku, II GSK 1933/12, LEX nr 1495128; wyrok NSA z dnia 26 lutego 2014 roku, II GSK 1868/12, LEX nr 1495116.

${ }^{64}$ B. Adamiak, [w:] B. Adamiak, J. Borkowski, Postępowanie administracyjne i sadowoadministracyjne, Warszawa 2017, s. 577-578. 
tem rzadkością są sytuacje, gdy ustalają one fakty. Co więcej, NSA jawi się jako podmiot dysponujący kompetencjami kasacyjnymi w stosunku do orzeczeń sądów administracyjnych, a nie aktów lub czynności administracji publicznej ${ }^{65}$. Podobne zapatrywania na tę kwestię wyrażano w orzecznictwie ${ }^{66}$.

Zgodnie z drugim, przeważającym poglądem kontrola instancyjna sprawowana przez NSA musi obejmować oba aspekty stosowania prawa przez wojewódzkie sądy administracyjne, to znaczy zarówno przepisy normujące tok procedowania tych sądów, jak również prawidłowość dokonanej przez te sądy oceny przepisów prawa, które miały mieć zastosowanie w rozpoznawanej sprawie ${ }^{67}$. Podnosi się ponadto, że niedostrzeżenie naruszenia prawa również stanowi naruszenie prawa, które świadczy o zaniechaniu realizacji, a co najmniej o niewłaściwej realizacji funkcji kontrolnej sądu, a dodatkowo o naruszeniu wynikającego z art. $141 \S 4$ p.p.s.a. obowiązku przedstawienia stanu sprawy, a błędne oddalenie skargi narusza także art. 151 p.p.s.a. Przedstawione naruszenia mogą być podstawą skargi kasacyjnej wymienioną w przepisie art. 174 pkt 2 p.p.s.a. ${ }^{68}$ Zaznacza się też, że może zostać podniesione w ramach podstawy kasacyjnej określonej w przepisie art. 174 pkt 2 p.p.s.a. niedostrzeżenie przez wojewódzki sąd administracyjny naruszenia przez organ podatkowy w toku postępowania podatkowego przepisów tego postępowania $^{69}$. Podnosi się także, że skoro

NSA rozpoznając skargę kasacyjną kontroluje bezpośrednio orzeczenie wojewódzkiego sądu administracyjnego i bada, czy sąd ten dokonał prawidłowej oceny legalności aktu administracyjnego, to pośrednio kontroluje legalność działania administracji publicznej. Konieczność objęcia kontrolą NSA naruszeń prawa procesowego przez organ administracji publicznej wyprowadzić można z [...] przepisów Konstytucji $\mathrm{RP}^{70}$.

Wątpliwości co do zakresu użytego w przepisie art. 174 pkt 2 p.p.s.a. pojęcia „przepisy postępowania” starał się wyjaśnić Naczelny Sąd Administracyjny, podejmując w pełnym składzie uchwałę wyjaśniającą, zainicjowaną wnioskiem Prezesa NSA. Dnia 26 października 2009 roku Naczelny Sąd Administracyjny w pełnym składzie podjął uchwałę o następującej treści:

Przytoczenie podstaw kasacyjnych, rozumiane jako wskazanie przepisów, które - zdaniem wnoszącego skargę kasacyjną — zostały naruszone przez wojewódzki sąd administracyjny, nakłada

65 Z. Kmieciak, Podstawy skargi kasacyjnej..., s. 23-25.

66 Wyrok NSA z dnia 16 grudnia 2004 roku, FSK 940/04, LEX nr 799395; wyrok NSA z dnia 21 grudnia 2004 roku, FSK 795/04, LEX nr 799313; wyrok NSA z dnia 11 lutego 2005 roku, FSK 923/04, LEX nr 799390; wyrok NSA z dnia 11 lutego 2005 roku, FSK 921/04, LEX nr 799388; wyrok NSA z dnia 21 kwietnia 2004 roku, FSK 181/04, LEX nr 125787; wyrok NSA z dnia 26 stycznia 2007 roku, II FSK 144/06, LEX nr 291469.

67 J.P. Tarno, op. cit., s. 457.

68 B. Dauter, B. Gruszczyński, op. cit., s. 503-504.

69 S. Babiarz, K. Aromiński, op. cit., s. 210.

70 G. Rząsa, Glosa do wyroku Trybunatu Konstytucyjnego z dnia 20 września 2006 r., (sygn. akt SK 63/05), „Przegląd Sejmowy” 2008, nr 4, s. 215. 
na Naczelny Sąd Administracyjny, stosownie do art. 174 pkt 1 i 2 oraz art. $183 \S 1$ ustawy z dnia 30 sierpnia 2002 r. - Prawo o postępowaniu przed sądami administracyjnymi (Dz.U. Nr 153, poz. 1270 ze zm.), obowiązek odniesienia się do wszystkich zarzutów przytoczonych w podstawach kasacyjnych ${ }^{71}$.

W uzasadnieniu prawnym tej uchwały podniesiono, że ustawodawca, nie precyzując bliżej w przepisie art. 174 pkt 2 p.p.s.a. ani charakteru postępowania, ani charakteru sprawy, której naruszenie to miałoby dotyczyć, świadomie przyjął formułę otwartej stylizacji normy wynikającej z powołanego przepisu. Wskazano ponadto, że w innych przepisach p.p.s.a. ustawodawca zastosował zabieg legislacyjny polegający na sprecyzowaniu tych kwestii, czyli charakteru postępowania i charakteru sprawy. Zdaniem NSA przy założeniu racjonalności ustawodawcy należy dojść do wniosku, że powyższy zabieg nie jest przypadkowy. Mając na uwadze opisane rozważania, NSA uznał, że wobec nieokreślenia przez ustawodawcę w przepisie art. 174 pkt 2 p.p.s.a., jakich przepisów postępowania ów przepis dotyczy, oraz w obliczu faktu, iż skoro ustawodawca, ograniczając stosowanie danej instytucji proceduralnej odpowiednio do postępowania sądowoadministracyjnego lub do postępowania administracyjnego, każdorazowo bliżej określa, o którą z procedur chodzi, to nie ulega wątpliwości, że wskazana w art. 174 pkt 2 p.p.s.a. podstawa kasacyjna odnosi się do naruszenia przepisów obu tych postępowań, a więc przepisów postępowania zarówno administracyjnego, jak i sądowoadministracyjnego. NSA wskazał ponadto, że po uwzględnieniu kontekstu systemowego przepisu art. 174 pkt 2 p.p.s.a. nie sposób przyjąć odmiennego niż przedstawiony wyżej wniosku. Przyjęcie różnego znaczenia niweczyłoby istotę sądowej kontroli administracji. W swoich rozważaniach NSA odniósł się również do dyrektyw wykładni funkcjonalnej, uznając, że celem skargi kasacyjnej w postępowaniu sądowoadministracyjnym jest umożliwienie stronie niezadowolonej z wyroku, w którym sąd pierwszej instancji dokonał oceny naruszenia przepisów postępowania administracyjnego, weryfikacji prawidłowości oceny naruszenia właśnie owych przepisów postępowania administracyjnego dokonanej przez NSA w granicach zakreślonych podstawą kasacyjną wymienioną w art. 174 pkt 2 p.p.s.a. Przyjęcie tego kierunku wykładni pozostaje w zgodzie z postanowieniami art. 184 Konstytucji RP, kreującymi obowiązek kontroli działalności administracji publicznej przez sądy administracyjne, do których należy Naczelny Sąd Administracyjny.

Przywołana uchwała, mająca w swym założeniu ostatecznie rozstrzygnąć wątpliwość, czy naruszenie przepisów postępowania administracyjnego może być samodzielną podstawą skargi kasacyjnej na podstawie przepisu art. 174 pkt 2 p.p.s.a., spotkała się ostatecznie z krytyką. W zgłoszonych do niej zdaniach odrębnych słusznie podnoszono, że postawione przez Prezesa NSA pytanie jest w zasadzie pytaniem retorycznym, z którego nie wynika jakakolwiek wątpliwość wymagająca rozstrzygnięcia, albowiem w orzecznictwie sądów administracyjnych nigdy nie

71 Uchwała pełnego składu NSA z dnia 26 października 2009 roku, I OPS 10/09, LEX nr 524941. 
kwestionowano obowiązku odniesienia się do wszystkich zarzutów skargi kasacyjnej. Podzielając te argumenty, M. Wilbrandt-Gotowicz wskazała ponadto, że posługiwanie się formułą „otwartej stylizacji” względem art. 174 p.p.s.a. należy uznać za bezzasadne, albowiem ze względu na przedmiot regulacji p.p.s.a. nie sposób odnosić sformułowania „postępowanie” do jakiegokolwiek innego postępowania niż postępowanie sądowoadministracyjne. Co więcej, ilekroć ustawodawca ma na myśli postępowanie administracyjne, formułuje to wprost, jak na przykład w przepisie art. $61 \S 2$ p.p.s.a. ${ }^{72}$

W doktrynie prezentowano również zgoła inne stanowiska. R. Kubacki wskazuje, że powyższa uchwała ułatwi pełniejszą realizację konstytucyjnej zasady dwuinstancyjności postępowania. Jego zdaniem za niepoprawne, w świetle podjętej przez pełny skład NSA uchwały, należy uznać działania NSA, poprzez które dyskwalifikuje się skargę kasacyjną wyłącznie przez fakt powołania się strony na zarzut naruszenia prawa przez organ administracji publicznej, nie powiązawszy go zarazem z zarzutem naruszenia prawa przez wojewódzki sąd administracyjny ${ }^{73}$. Zasadnie podnosi się ponadto, że ta uchwała ma do dziś istotne znaczenie dla prawidłowej wykładni przez NSA podstaw skargi kasacyjnej. Jej podjęcie w pełnym składzie przyczyniło się nie tylko do ujednolicenia orzecznictwa sądowego, lecz przede wszystkim do zwiększenia dostępności, upowszechnienia skargi kasacyjnej, która w postępowaniu sądowoadministracyjnym pełni funkcję zwyczajnego środka zaskarżenia ${ }^{74}$. J.P. Tarno wskazuje dodatkowo, że przywołana uchwała powinna być skutecznym instrumentem zapewniającym jednolitość orzecznictwa w zakresie rozumienia podstaw kasacyjnych. Autor prezentuje również dalej idący pogląd, że orzeczenie sądu administracyjnego sprzeczne ze stanowiskiem wskazanym w uchwale poszerzonego składu NSA pozbawia stronę możliwości obrony swojego interesu prawnego i tym samym narusza przepisy postępowania powodujące nieważność postępowania i będące jednocześnie przesłanką do jego wznowienia na podstawie przepisu art. 271 pkt 2 p.p.s.a. ${ }^{75}$

Odnosząc się do poczynionych rozważań, należy dojść do przekonania, że mimo licznych kontrowersji związanych z tą uchwałą znacznie przyczyniła się ona do zapewnienia skarżącym dostępu do sądu odwoławczego. Wyznaczyła bowiem kierunek wykładni, który zdaje się zapewniać skarżącym skuteczny środek odwoławczy od orzeczeń sądów administracyjnych pierwszej instancji, również

72 M. Wilbrandt-Gotowicz, Postępowanie kasacyjne, „Glosa” 2010, nr 2, s. 108 - glosa do uchwały NSA z 26 października 2009 roku, I OPS 10/09.

73 R. Kubacki, Podstawy skargi kasacyjnej w zakresie naruszenia przepisów postępowania, „Monitor Podatkowy” 2010, nr 1, s. 12-13.

74 R. Hauser, W. Piątek, A. Skoczylas, op. cit., s. 453.

75 J.P. Tarno, Ewolucja orzecznictwa Naczelnego Sadu Administracyjnego w zakresie podstaw skargi kasacyjnej i zażalenia, „Zeszyty Naukowe Sądownictwa Administracyjnego” 2010, nr 5-6, s. 441-442. 
w wypadkach gdy sądy te nie dostrzegły naruszeń prawa popełnionych przez organy administracji publicznej.

\section{Naruszenie przepisów prawa ustrojowego}

Opracowanego w doktrynie trójpodziału norm prawa administracyjnego na normy prawa: materialnego, proceduralnego i ustrojowego zdaje się nie uwzględniać katalog podstaw kasacyjnych wskazany w przepisie art. 174 p.p.s.a. Powyższy przepis nie odnosi się bowiem do możliwości naruszenia przez wojewódzki sąd administracyjny norm prawa ustrojowego.

Odnośnie do pojęcia norm administracyjnego prawa ustrojowego w doktrynie wskazuje się, że „Normy te określają status prawny organów administracji publicznej, ustalają wzajemne powiązania organów administracyjnych, ich układ hierarchiczny, wyposażają je także w określone uprawnienia do wykonywania władztwa administracyjnego"76. Treść przepisu art. 174 p.p.s.a. zdaje się pomijać naruszenie norm prawa ustrojowego, co z kolei rodzi następujące pytania: czy możliwe jest podniesienie w skardze kasacyjnej zarzutu naruszenia przepisów prawa ustrojowego oraz, w razie pozytywnej odpowiedzi na pierwsze pytanie, na podstawie której z przesłanek wskazanych w przepisie art. 174 p.p.s.a. skarżący powinien opierać tego rodzaju zarzut.

Początkowo Naczelny Sąd Administracyjny, opierając się na literalnym brzmieniu przepisu art. 174 p.p.s.a., zajął stanowisko, że przepisy prawa ustrojowego nie mogą stanowić skutecznej podstawy kasacyjnej oraz nie są podstawą, na której można by oprzeć skargę kasacyjną od orzeczenia sądu pierwszej instancji ${ }^{77}$. Stanowisko to spotkało się z otwartą krytyką. Jak słusznie zauważył Z. Kmieciak, utrwalenie się go w praktyce skutkowałoby ograniczeniem zakresu ochrony, którą ma zapewniać skarga kasacyjna. W istocie wiązałoby się to ze zróżnicowaniem stopnia ochrony sądowej ze względu na kryteria przedmiotowe i podmiotowe właściwe dla rozpoznawanych spraw ${ }^{78}$.

Kluczowa do jednoznacznego określenia dopuszczalności stawiania zarzutu naruszenia prawa ustrojowego w skardze kasacyjnej była opisana wcześniej uchwała pełnego składu NSA z dnia 26 października 2009 roku (I OPS 10/09). W uzasadnieniu do tej uchwały jednoznacznie wskazano, że naruszeniem prawa, które można zakwalifikować do grupy naruszenia prawa ustrojowego będzie głównie naruszenie przepisów o właściwości organów, przepisów kształtujących ich ustrój oraz działanie organów bez podstawy prawnej. NSA uznał, że sytuacja, w której

76 H. Knysiak-Sudyka, op. cit., s. 232.

77 Wyrok NSA z dnia 30 czerwca 2005 roku, I FSK 295/05, LEX nr 175284; wyrok NSA z dnia 13 października 2005 roku, OSK 1932/04, LEX nr 201367.

78 Z. Kmieciak, Podstawy skargi kasacyjnej do Naczelnego Sadu Administracyjnego, „Gdańskie Studia Prawnicze - Przegląd Orzecznictwa" 2007, nr 2, s. 46 - glosa do wyroku NSA z dnia 13 października 2005 roku, OSK 1932/04. 
dochodzi do naruszenia przez organ administracji przepisu ustrojowego w przyjętym rozumieniu, w przeważającej większości wypadków będzie kwalifikowana jako przyczyna nieważności decyzji (postanowienia). W sytuacji gdy w przekonaniu WSA zaszła któraś z przesłanek określonych w przepisie art. $156 \S 1$ k.p.a., sąd ten jest zobowiązany stwierdzić nieważność takiego aktu administracyjnego na podstawie przepisu art. $145 \S 1$ pkt 2 p.p.s.a. względnie — w razie gdy stwierdzenie nieważności nie może nastąpić (art. $156 \S 2$ k.p.a.) — stwierdzić wydanie takiego aktu z naruszeniem prawa, na podstawie przepisu art. $145 \S 1$ pkt 3 p.p.s.a. $Z$ kolei naruszenie przepisu ustrojowego niedające się zakwalifikować jako przesłanka stwierdzenia nieważności postępowania administracyjnego powinno być potraktowane jako naruszenie przez organ administracji prawa materialnego lub prawa procesowego i jako takie obliguje sąd administracyjny do uchylenia takiego rozstrzygnięcia na podstawie art. $145 \S 1$ pkt 1 lit. a-c p.p.s.a. Dokonanie zaś przez wojewódzki sąd administracyjny nieprawidłowej oceny naruszenia przez organ administracji przepisów ustrojowych może być podstawą skargi kasacyjnej, za czym przemawiają te same powody, które odnoszą się do naruszenia prawa materialnego i przepisów o postępowaniu administracyjnym ${ }^{79}$.

Tak jednoznacznie rozumiane stanowisko NSA poskutkowało tym, że obecnie w orzecznictwie nie budzi wątpliwości dopuszczalność powoływania w skardze kasacyjnej zarzutów naruszenia przepisów ustrojowych ${ }^{80}$.

W doktrynie i orzecznictwie ukształtowały się dwa poglądy co do tego, na podstawie której ze skarg kasacyjnych należy formułować zarzut naruszenia prawa ustrojowego. Jak bowiem wskazano, regulujący podstawy skargi kasacyjnej przepis art. 174 p.p.s.a. nie zawiera w swoim katalogu możliwych uchybień naruszenia prawa ustrojowego.

Zgodnie $\mathrm{z}$ jednym poglądem naruszenie prawa ustrojowego powinno być podnoszone $\mathrm{w}$ ramach podstawy wskazanej w przepisie art. 174 pkt 1 p.p.s.a., to jest podstawy określającej naruszenie prawa materialnego, a to ze względu na specyficzną - bliższą niż z prawem procesowym - relację prawa ustrojowego $\mathrm{z}$ prawem materialnym ${ }^{81}$.

79 Uchwała pełnego składu NSA z dnia 26 października 2009 roku, I OPS 10/09, LEX nr 524941.

80 Wyrok NSA z dnia 23 listopada 2018 roku, I OSK 187/17, LEX nr 2597890; wyrok NSA z dnia 30 maja 2012 roku, I GSK 748/11, LEX nr 1243968; wyrok NSA z dnia 31 maja 2019 roku, II GSK 2841/17, LEX nr 2694038.

81 W. Piątek, op. cit., s. 313; R. Hauser, W. Piątek, A. Skoczylas, op. cit., s. 455; B. Adamiak, [w:] B. Adamiak, J. Borkowski, Postepowanie..., s. 575; B. Adamiak, J. Borkowski, Metodyka pracy sędziego w..., s. 328; Z. Kmieciak, Podstawy... - glosa, s. 46-47; wyrok NSA z dnia 26 kwietnia 2006 roku, II GSK 36/06, LEX nr 319141; wyrok NSA z dnia 20 stycznia 2009 roku, II GSK 675/08, LEX nr 481511; wyrok NSA z dnia 20 maja 2011 roku, I OSK 1040/10, LEX nr 1080854; wyrok NSA z dnia 10 lutego 2011 roku, I OSK 875/10, LEX nr 1070869. 
Drugi, przeważający obecnie w doktrynie i orzecznictwie pogląd zakłada, że zarzut naruszenia prawa ustrojowego winien być podniesiony $\mathrm{w}$ ramach drugiej z podstaw kasacyjnych, czyli na podstawie przepisu art. 174 pkt 2 p.p.s.a. Wskazuje się bowiem, że przepisy prawa ustrojowego są bliższe przepisom prawa procesowego niż materialnego ${ }^{82}$.

Poczynione rozważania prowadzą do wniosku, że mimo pominięcia w kata$\operatorname{logu}$ zawartym w przepisie art. 174 p.p.s.a. naruszenia norm prawa ustrojowego możliwe jest skuteczne postawienie zarzutu jego naruszenia w skardze kasacyjnej. Należy jednak pamiętać, że taki zarzut będzie musiał zostać oparty na podstawach kasacyjnych funkcjonujących obecnie w przepisie art. 174 p.p.s.a.

\section{Zakończenie}

Mimo pojawiających się w doktrynie postulatów konieczności zmiany przepisu art. 174 p.p.s.a. w celu zapewnienia skarżącym możliwości skorzystania z realnej kontroli instancyjnej ${ }^{83}$ należy uznać, że ten efekt został osiągnięty dzięki zabiegom interpretacyjnym podjętym przez orzecznictwo i doktrynę. Należy bowiem pamiętać, że skarga kasacyjna w postępowaniu sądowoadministracyjnym została zaprojektowana na podstawie istniejącej wcześniej w postępowaniu cywilnym instytucji kasacji (obecnie skargi kasacyjnej). Nie wymaga głębszego wyjaśnienia dostrzegalna na pierwszy rzut oka różnica między tymi postępowaniami. Ogólnie rzecz ujmując, istotą postępowania cywilnego jest rozstrzyganie przez sąd cywilny sporów cywilnoprawnych między dwoma równorzędnymi podmiotami. Rolą zaś postępowania sądowoadministracyjnego jest kontrola legalności działań organów administracji publicznej. Co więcej, skargi kasacyjne w obu tych postępowaniach pełnią zupełnie odmienne funkcje - w postępowaniu cywilnym stanowi ona nadzwyczajny środek zaskarżenia od prawomocnych orzeczeń, w postępowaniu zaś sądowoadministracyjnym pełni funkcję środka odwoławczego od orzeczeń sądów administracyjnych pierwszej instancji. Skoro zatem podstawy skargi kasacyjnej w postępowaniu sądowoadministracyjnym ustawodawca zaprojektował na podstawie istniejącej wcześniej regulacji prawnej z postępowania cywilnego, to bez wątpienia koniecznością było podjęcie przez naukę i sądownictwo wszelkich możliwych zabiegów interpretacyjnych, mających zapewnić pełną i skuteczną realiza-

82 B. Dauter, op. cit., s. 536; B. Dauter, B. Gruszczyński, op. cit., s. 544; M. Kania, Zwyczajne środki zaskarżenia w postępowaniu przed sadami administracyjnymi, Warszawa 2009, s. 135; wyrok NSA z dnia 23 listopada 2018 roku, I OSK 187/17, LEX nr 2597890; wyrok NSA z dnia 30 maja 2012 roku, I GSK 748/11, LEX nr 1243968; wyrok NSA z dnia 31 maja 2019 roku, II GSK 2841/17, LEX nr 2694038; wyrok NSA z dnia 5 kwietnia 2011 roku, II GSK 422/10, LEX nr 992384.

83 Z. Kmieciak, Podstawy... — glosa, s. 47; Z. Kmieciak, Podstawy skargi kasacyjnej..., s. 27; Z. Kmieciak, Zakres pojęcia naruszenie przepisów postępowania stanowiącego podstawę skargi kasacyjnej. Glosa do wyroku NSA z dnia 16 stycznia 2006 r., I OPS 4/05, „Państwo i Prawo” 2006, nr 9, s. 128. 
cję zasady dwuinstancyjnego postępowania w postępowaniu sądowoadministracyjnym. Osiągnięcia doktryny i orzecznictwa w tym zakresie - choć nie wolne od zastrzeżeń — należy ocenić pozytywnie. Na skutek tego obecnie możliwe jest uzyskanie przez skarżącego ochrony prawnej w wypadku naruszenia prawa ustrojowego, a zarzut naruszenia przepisów postępowania administracyjnego przez organ administracji publicznej nie będzie powodował odrzucenia skargi kasacyjnej i jako taki zostanie merytorycznie rozpoznany. Dzięki tym zabiegom skarga kasacyjna w postępowaniu sądowoadministracyjnym jest realnym i skutecznym środkiem odwoławczym.

\section{Bibliografia}

Adamiak B., [w:] B. Adamiak, J. Borkowski, Postępowanie administracyjne i sądowoadministracyjne, Warszawa 2017.

Adamiak B., Skarga i skarga kasacyjna w postępowaniu sądowoadministracyjnym. Komentarz, Warszawa 2017.

Babiarz S., Aromiński K., [w:] Postępowanie sądowoadministracyjne w praktyce, red. S. Babiarz, Warszawa 2015.

Borkowski G., Skarga kasacyjna - po roku obowiazywania ustawy, „Monitor Podatkowy” 2005, nr 3.

Borkowski J., [w:] B. Adamiak, J. Borkowski, Metodyka pracy sędziego w sprawach administracyjnych, Warszawa 2015.

Dauter B., Metodyka pracy sędziego sądu administracyjnego, Warszawa 2012.

Dauter B., Gruszczyński B., [w:] Prawo o postępowaniu przed sądami administracyjnymi. Komentarz, red. B. Dauter, B. Gruszczyński, A. Kabat, M. Niezgódka-Medek, wyd. 4, Warszawa 2011.

Drachal J., Wiktorowska A., Stankiewicz R., [w:] Prawo o postepowaniu przed sadami administracyjnymi. Komentarz, red. R. Hauser, M. Wierzbowski, Warszawa 2017.

Duniewska Z., [w:] System Prawa Administracyjnego, t. 1. Instytucje prawa administracyjnego, red. R. Hauser, Z. Niewiadomski, A. Wróbel, Warszawa 2015.

Ereciński T., [w:] Kodeks postępowania cywilnego. Komentarz, t. 3. Postępowanie rozpoznawcze, red. T. Ereciński, Warszawa 2016.

Hauser R., Piątek W., Skoczylas A., [w:] System Prawa Administracyjnego, t. 10. Sadowa kontrola administracji publicznej, red. R. Hauser, Z. Niewiadomski, A. Wróbel, Warszawa 2016.

Jagielski J., [w:] System Prawa Administracyjnego, t. 7. Prawo administracyjne materialne, red. R. Hauser, Z. Niewiadomski, A. Wróbel, Warszawa 2012.

Kania M., Zwyczajne środki zaskarżenia w postępowaniu przed sąami administracyjnymi, Warszawa 2009.

Kmieciak Z., Czy sady administracyjne stosuje przepisy prawa materialnego?, „Zeszyty Naukowe Sądownictwa Administracyjnego" 2011, nr 2.

Kmieciak Z., Podstawy skargi kasacyjnej do Naczelnego Sadu Administracyjnego, „Gdańskie Studia Prawnicze - Przegląd Orzecznictwa" 2007, nr 2.

Kmieciak Z., Podstawy skargi kasacyjnej do Naczelnego Sąu Administracyjnego, „Państwo i Prawo" 2005, nr 1, s. 21.

Kmieciak Z., Zakres pojęcia naruszenie przepisów postępowania stanowiacego podstawę skargi kasacyjnej. Glosa do wyroku NSA z dnia 16 stycznia 2006 r., I OPS 4/05, „Państwo i Prawo” 2006, nr 9 .

Studenckie Prace Prawnicze, Administratywistyczne

i Ekonomiczne 30, 2019

(C) for this edition by CNS 
Knysiak-Sudyka H., Skarga i skarga kasacyjna w postępowaniu sadowoadministracyjnym, Warszawa 2016.

Kubacki R., Podstawy skargi kasacyjnej w zakresie naruszenia przepisów postępowania, „Monitor Podatkowy" 2010, nr 1.

Lapierre J., [w:] J. Jodłowski, Z. Resich, J. Lapierre, T. Misiuk-Jodłowska, K. Weitz, Postępowanie cywilne, Warszawa 2016.

Niezgódka-Medek M., [w:] Prawo o postępowaniu przed sadami administracyjnymi. Komentarz, red. B. Dauter, A. Kabat, M. Niezgódka-Medek, Warszawa 2016.

Piątek W., Podstawy skargi kasacyjnej w postęowaniu sądowoadministracyjnym, Warszawa 2011.

Piotrowska A., [w:] Kodeks postępowania cywilnego, t. 2, red. A. Marciniak, K. Piasecki, Warszawa 2016.

Rząsa G., Glosa do wyroku Trybunału Konstytucyjnego z dnia 20 września 2006 r., (sygn. akt SK 63/05), ,Przegląd Sejmowy” 2008, nr 4.

Rząsa G., Podstawy skargi kasacyjnej w postępowaniu sądowoadministracyjnym, „Państwo i Prawo" 2008 , nr 8.

Tarno J.P., Ewolucja orzecznictwa Naczelnego Sadu Administracyjnego w zakresie podstaw skargi kasacyjnej i zażalenia, „Zeszyty Naukowe Sądownictwa Administracyjnego” 2010, nr 5-6.

Tarno J.P., Prawo o postępowaniu przed sądami administracyjnymi. Komentarz, Warszawa 2012.

Wilbrandt-Gotowicz M., Postepowanie kasacyjne, „Glosa” 2010, nr 2.

Wróblewski J., Sąowe stosowanie prawa, Warszawa 1972.

Zieliński A., [w:] Kodeks postępowania cywilnego. Komentarz, red. A. Zieliński, Warszawa 2017.

\section{Akty prawne}

Konstytucja Rzeczypospolitej Polskiej z dnia 2 kwietnia 1997 roku (Dz.U. z 1997 r. Nr 78, poz. 483, z późn. zm.).

Ustawa z dnia 17 listopada 1964 roku Kodeks postępowania cywilnego (Dz.U. z 2019 r. poz. 1460 z poźn. zm.).

Ustawa z dnia 1 marca 1996 roku o zmianie Kodeksu postępowania cywilnego, rozporządzeń Prezydenta Rzeczypospolitej — Prawo upadłościowe i Prawo o postępowaniu układowym, Kodeksu postępowania administracyjnego, ustawy o kosztach sądowych w sprawach cywilnych oraz niektórych innych ustaw (Dz.U. z 1996 r. Nr 43, poz. 189).

Ustawa z dnia 30 sierpnia 2002 roku Prawo o postępowaniu przed sądami administracyjnymi. (Dz.U. z 2018 r. poz. 1302 z późn. zm.).

Ustawa $\mathrm{z}$ dnia 22 grudnia 2004 roku o zmianie ustawy Kodeks postępowania cywilnego oraz ustawy Prawo o ustroju sądów powszechnych (Dz.U. z 2005 r. Nr 13, poz. 98).

\section{Orzecznictwo}

Uchwała pełnego składu NSA z dnia 26 października 2009 roku, I OPS 10/09, LEX nr 524941.

Wyrok ETPCz z dnia 10 kwietnia 2008 roku, nr skargi 21071/05, LEX nr 370471.

Wyrok SN z dnia 10 listopada 2010 roku, I UK 135/10, LEX nr 707407.

Wyrok SN z dnia 24 marca 2011 roku, I UK 317/10, LEX nr 1130858.

Wyrok NSA z dnia 21 kwietnia 2004 roku, FSK 181/04, LEX nr 125787.

Wyrok NSA z dnia 24 maja 2004 roku, FSK 78/04, LEX nr 707780.

Wyrok NSA z dnia 24 maja 2004 roku, FSK 79/04, LEX nr 109935.

Wyrok NSA z dnia 7 października 2004 roku, FSK 558/04, LEX nr 251771.

Wyrok NSA z dnia 16 grudnia 2004 roku, FSK 940/04, LEX nr 799395.

Wyrok NSA z dnia 21 grudnia 2004 roku, FSK 795/04, LEX nr 799313.

Wyrok NSA z dnia 11 lutego 2005 roku, FSK 921/04, LEX nr 799388.

Studenckie Prace Prawnicze, Administratywistyczne

i Ekonomiczne 30, 2019

(C) for this edition by CNS 
Wyrok NSA z dnia 11 lutego 2005 roku, FSK 923/04, LEX nr 799390.

Wyrok NSA z dnia 30 czerwca 2005 roku, I FSK 295/05, LEX nr 175284. Wyrok NSA z dnia 8 września 2005 roku, OSK 1950/04, LEX nr 194728. Wyrok NSA z dnia 13 września 2005 roku, II OSK 16/05, LEX nr 192124. Wyrok NSA z dnia 13 października 2005 roku, OSK 1932/04, LEX nr 201367. Wyrok NSA z dnia 16 grudnia 2005 roku, I FSK 423/05, LEX nr 187703. Wyrok NSA z dnia 26 kwietnia 2006 roku, II GSK 36/06, LEX nr 319141. Wyrok NSA z dnia 27 czerwca 2006 roku, I OSK 641/05, LEX nr 266347. Wyrok NSA z dnia 6 lipca 2006 roku, I FSK 1122/05, LEX nr 279043. Wyrok NSA z dnia 27 lipca 2006 roku, I FSK 1130/05, LEX nr 279045. Wyrok NSA z dnia 27 lipca 2006 roku, I FSK 643/05, LEX nr 279049. Wyrok NSA z dnia 21 września 2006 roku, I FSK 594/05, LEX nr 280933. Wyrok NSA z dnia 26 stycznia 2007 roku, II FSK 144/06, LEX nr 291469. Wyrok NSA z dnia 20 stycznia 2009 roku, II GSK 675/08, LEX nr 481511. Wyrok NSA z dnia 10 lutego 2011 roku, I OSK 875/10, LEX nr 1070869. Wyrok NSA z dnia 5 kwietnia 2011 roku, II GSK 422/10, LEX nr 992384. Wyrok NSA z dnia 18 maja 2011 roku, I OSK 114/11, LEX nr 990149. Wyrok NSA z dnia 20 maja 2011 roku, I OSK 1040/10, LEX nr 1080854. Wyrok NSA z dnia 9 grudnia 2011 roku, II FSK 1142/10. LEX 1112709. Wyrok NSA z dnia 20 marca 2012 roku, II FSK 1760/10, LEX nr 1295991. Wyrok NSA z dnia 30 maja 2012 roku, I GSK 748/11, LEX nr 1243968. Wyrok NSA z dnia 20 lutego 2014 roku, II GSK 1933/12, LEX nr 1495128. Wyrok NSA z dnia 26 lutego 2014 roku, II GSK 1868/12, LEX nr 1495116. Wyrok NSA z dnia 3 kwietnia 2014 roku, II OSK 2664/12. LEX nr 1575562. Wyrok NSA z dnia 5 czerwca 2014 roku, I OSK 294/14, LEX nr 1518050. Wyrok NSA z dnia 11 czerwca 2014 roku, I OSK 575/14, LEX nr 1484868. Wyrok NSA z dnia 15 lutego 2017 roku, II FSK 2986/16, LEX nr 2270044. Wyrok NSA z dnia 6 czerwca 2017 roku, I OSK 2354/15, LEX nr 2468901. Wyrok NSA z dnia 23 listopada 2018 roku, I OSK 187/17, LEX nr 2597890. Wyrok NSA z dnia 27 lutego 2019 roku, II OSK 910/17, LEX nr 2639398. Wyrok NSA z dnia 31 maja 2019 roku, II GSK 2841/17, LEX nr 2694038. Wyrok NSA z dnia 29 sierpnia 2019 roku, I OSK 2554/18, LEX nr 2725491.

\section{Źródła internetowe}

http://orka.sejm.gov.pl/Druki4ka.nsf/(\$vAllByUnid)/F1991C948C3387B5C1256AF100605584/\$fi le/19-uzasadnienie.pdf. https://sjp.pwn.pl/sjp/podstawa;2502784.html. 